baf- $\odot$

Proceedings of the Berner

Altorientalisches

Forum

ISSN 2504-2076

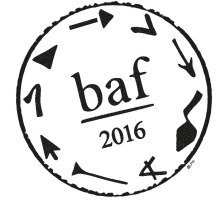

Abstract

Pavel Čech, Charles University in Prague

DOI: http://dx.doi.org/10.22012/baf.2016.10

\title{
Easy-going: the treatment of written records in the ancient Syropalestine
}

Who invented the Proto-Sinaitic writing? Sophisticated scribes, or unlettered workers? Orly Goldwasser, the chief advocate of the second possibility, borrowed from economic sciences the term 'disruptive innovation' that "describes a process by which a product or service takes root initially in simple applications at the bottom of a market and then relentlessly moves 'up market,' eventually displacing established competitors."'11] During the years spent with translations of Levantine texts for a Czech kind of „Context of Scripture“, I had an impression - however daring - that it is possible to generalize this finding for the Syropalestinian literature as a whole. Be it cuneiform or linear, narrative or Listenwissenschaft, [2] it shares the same basic tendency for simplicity and unambiguousness.

\section{Definitions}

Disruptive innovation: process by which a product or service takes root initially in simple applications at the bottom of a market and then relentlessly moves up market, eventually displacing established competitors

Center and Periphery: The centre-periphery model is a spatial metaphor which describes and attempts to explain the structural relationship between the advanced or metropolitan 'centre' and a less developed 'periphery'

[1] www.claytonchristensen.com/disruptive_innovation.html

[2] KTU 1.103 is a very special example from many points of view (and on the background of Y. Cohen, Akkadian Omens from Hattuša and Emar. The šumma immeru and šumma ālu Omens, in: Zeitschrift für Assyriologie, 97, 2007, str. 233-251). 